\title{
COVID-19: scars of the virus and stories caused by social isolation and mourning
}

DClaudia Terezinha Moraes Pinheiro Delgado'

1. Universidade do Vale do Itajaí, R. Uruguai, 458 - Centro, Itajaí, SC, Brasil.

http://dx.doi.org/10.1590/1806-9282.66.11.1478

\section{SUMMARY}

We watch a variety of news on the Coronavirus daily. Some are reliable and others just instill more fear into the population. This article reflects on the possible consequences of this virus, which goes beyond the organic disease and the symptoms and signs mentioned daily in the media. Seeking a reflection on the effects caused indirectly by the virus. Since isolation precedes the disease, total isolation during the disease and isolation after the disease worsens, in some cases resulting in abrupt grief.

KEYWORDS: Coronavirus, grief, social isolation, loss, respiratory infections.

In December 2019, the health authorities in the city of Wuhan, Hubei Province (China), reported individuals diagnosed with severe acute respiratory syndrome of unknown origin. ${ }^{1}$

On 30 January, the World Health Organization $(\mathrm{WHO})^{2}$ declared an international emergency, and approximately two months later, on 11 March, $^{3}$ declared it a pandemic.

In Brasil, up to 08 of April 2020, there had been 15,927 COVID-19 cases. In the last 24 hours, 2,210 new cases of the disease were confirmed, which represents an increase of $16 \%(2.210 / 13.717)$ in comparison to the total accumulated up to the previous day, according to the WHO and Johns Hopkins University. ${ }^{4}$

Viruses are considered etiological agents that both predispose individuals to secondary bacterial infections and are dominant agents of acute respiratory insufficiency. We have observed severe clinical manifestations associated with diseases of the lower respiratory tract in people with risk factors such as: heart disease, lung disease among other chronic diseases such as hypertension, obesity, and diabetes. ${ }^{5.6}$

The Ministry of Health outlined as objectives of the SUS (Unified Health System) response to the Coronavirus disease, in its Epidemiological Bulletin, by the Center for Emergency Operations in Public Health, the following:

- Interrupting human to human transmission and mitigating events that broaden transmission;

- Timely identify suspected cases of flu and severe acute respiratory syndrome, based on clinical and laboratory diagnosis;

- Isolate symptomatic patients and provide care to patients;

- Promote studies to describe the natural history of the disease in Brasil, the pattern of transmission, severity, therapeutic options, the development of medicines and vaccines, in addition to contributing to the international effort to investigate gaps in the scientific knowledge about the disease; 
- Establish responsive mechanisms to register, purchase nationally and/or internationally, distribute, evaluate and monitor the quality of products, equipment, and inputs related to the pandemic response so as to stimulate national production;

- Establish institutional guidelines for the management and sharing of scientific data and deployment of good practices of science and open data, ensuring transparency and monitoring by the society and control bodies of all decision-making processes, daily, the epidemiological situation, risk situation, and advances in response at each stage of the pandemic;

- Minimize the social and economic impact through multisector partnerships and in support of measures for expanded and selective social distancing adopted by the States, Federal District, and Municipalities:

- Monitor notified cases and deaths, occupations and installation of beds, supplies of personal protective equipment, laboratory tests (serological and molecular), mechanical respirators, labor force, logistics, and communication. ${ }^{4}$

What still has had little repercussions are the consequences of this virus in the people affected by it, both directly, when they contract the virus and are required to socially isolate, or when they lose a loved one without the possibility of farewells, a funeral, or any other symbolism, religious or not, that somehow helps to deal with the mourning process.

Managing to juggle and minimize the economic, social, and psychological damages to the population by adopting fiscal and social measures is essential. ${ }^{7.8}$ What we seek as citizens is managers prepared to work in these areas, enabling health professionals and able to act in an interdisciplinary way.

Social isolation has already demonstrated to leave scars in previous times, as occurred in the mid $20^{\text {th }}$ century, when the country, with the intention of controlling and ending "leprosy", adopted the strategy of compulsory isolation. So, Hansen's disease patients were removed from public life, believing that by isolating the sick a healthy society would be preserved. Many people who were only suspected of having the disease, based on complaints from neighbors, were taken from their homes, which were later burned, suffering all the embarrassment caused by hospitalization. ${ }^{9}$
The suffering resulting from the social isolation of those people suffering from or suspected of having Hansen's disease, combined with the need for care, would mobilize them toward overcoming an experience of social segregation. Obviously, the different ways of coping depend on the perception of each individual and vary according to individual experiences. However, we can learn something from that past experience that is similar to what we are currently experiencing.

The virus, the social awareness, the people, the government, the latter not always, and fear itself make us isolate, either individually or in a "family", in small family bubbles. In the effort to not contract the virus, or to not pass it along to our loved ones, and in the expectation of a possible cure or protection.

The first consideration we report here is that we know that the feeling of isolation and lack of social support is a risk factor for suicide recognized by the World Health Organization. ${ }^{10,11}$ Suicide rates inversely vary with the degree of social integration of an individual. Studies have shown that unmarried individuals are $38 \%$ more likely to commit suicide. Recent migrants and people without religion also compose the variables identified as of risk for suicide. ${ }^{10}$

We must be vigilant and think about creating programs so that everyone can have social interaction, even if through technology, and by that we mean actual soft-hard technology, as in those available by computer, so that we can work on the soft technology, which would be providing refuge to others. Seek ways to integrate so we can overcome this isolation, whether it is temporary or not.

The current guidelines establish that after testing positive by RT-PCR or serological tests, individuals should be put on a 14-day leave from work. If it is not possible to get tested, but flu syndrome (symptoms) is present, guidelines establish the prescription of a 7-day leave from work, starting at the onset of symptoms, with a return to work after seven days, if the individual remains asymptomatic. Serological tests should be carried out on the eighth day after the onset of symptoms. ${ }^{4}$

Having explained the current guidelines, we present the second consideration, which regards the prejudice suffered by those who received a diagnosis or were given leave from work for presenting symptoms and find themselves isolated by everyone. This demonstrates that even if these individuals do not present symptoms or the possibility of transmission, they will 
remain in isolation, either by fear and insecurity that they can still transmit the virus or by the fear of others of contracting it.

And to those who lost relatives, there is the impossibility of a farewell, whether in life or in death. What are the long-term consequences that a disease with such transmission capacity and abrupt development can leave to those who continue living?

Death, in the Western world, is a taboo, surrounded by mysteries and beliefs, and people are often unprepared to deal with the human finitude. When a death occurs tragically and suddenly, it tends to cause numerous changes in a person's life, causing, oftentimes, damage and changes, particularly in emotional and cognitive functions. ${ }^{12}$

There are reports, according to Parkes, ${ }^{13}$ that people who lost a loved one, suddenly, wept more, felt numb and missed the loved one more than those who also lost a loved one bur in other circumstances. It was also observed that the sudden loss of children, in car accidents, caused in their parents more depression, anger, and guilt and, consequently, more health problems, in addition to painful memories of the person who died, than when a child dies due to a disease of which the parents are aware. In these descriptions, it is possible to note that sudden, unexpected, and early death is considered a complicating predictor to the usual mourning process and may lead to psychological problems such as depression and anxiety. ${ }^{12.13}$

Those in grief are left with the option of resorting to a psychologist, who also now provide remote care, by telephone, in order to provide refuge and listening to the patient. Follow-up with a psychologist can contribute to improvements in coping with this process. Considering that people experiencing the loss of a loved one are trying to find reasons, the details of the death (how it was, where it was), in their effort to find a rational understanding of how it happened, this is essential to alleviate their pain, anxiety, and confusion. ${ }^{12}$

\section{FINAL CONSIDERATIONS}

Given the scenario set out in this paper regarding ongoing social isolation and the possible sudden death of an individual or their family and acquaintances, all of which bring consequences as stressful life events, caused by a virus that removes people from their core and context, what is left, beyond doubt, is loss and isolation that lead to suffering and of great psychological changes. It is necessary to have managers who are attentive to needs that are changing and who can creatively provide adjustments to deal with these new financial, emotional, social, and affective shortcomings. Society needs to learn how to move forward and provide refuge to all those who went through this isolation, i.e. Society as a whole, globally, since this is a pandemic virus.

Those in mourning require increasingly more the assistance of a psychologist, a health professional who will assist them by listening and providing refuge to the weakened human being who survived. More studies and reflections deserve to be shared so that we can together not feel so alone, sharing knowledge and possibly different contexts, which involve several countries. Since there are not many Brazilian studies that address the grief generated by a sudden loss in this proposed references, i.e., on the impossibility of a farewell, it is important to highlight that new research should be carried out, and we can provide interested professionals updated materials on this topic.

\section{RESUMO}

Observamos diariamente uma variedade de notícias sobre o Coronavirus. Algumas confiáveis e outras apenas para causar mais temor para a população. Este artigo realiza uma reflexão sobre possíveis consequências desse vírus, que vai além da doença orgânica e dos sintomas e sinais referidos diariamente nos meios de comunicação. Buscando uma reflexão sobre efeitos ocasionados indiretamente pelo vírus. Sendo o isolamento antecedente a doença, isolamento total durante a doença e isolamento posterior a agudização da doença, em alguns casos resultando em luto abrupto.

PALAVRAS CHAVE: Coronavírus, luto, isolamento social, perdas, infecções respiratórias. 


\section{REFERENCES}

1. LAURENTE, Itala; CHIRE, Josimar. Impacto das pesquisas científicas das universidades paulistas nos principais jornais sobre a covid-19. 2020.Disponível em: https://ige.unicamp.br/sites/portal8.ige.unicamp.br.portal/ files/eventos/2020-05/boletim\%204\%20-\%20Universidade\%20e\%20 Jornais\%20\%281\%29.pdf Acesso em 14 jul 2020.

2. WHO. World Health Organization. Director-General's statement on IHR Emergency Committee on Novel Coronavirus (2019-nCoV) 2020. Disponível: https://www.who.int/dg/speeches/detail/whodirector-general-s-statement-on-ihr-emergencycommittee-on-novel-coronavirus-(2019-ncov). Acesso em 17 Jul 2020

3. WHO. World Health Organization. Director-General's opening remarks at the media briefing onCOVID-19. Disponível em: https://www.who.int/dg/ speeches/detail/whodirector-general-s-opening-remarks-at-the-mediabriefing-on-covid-19-11-march-2020 Acesso em Jul 20 Jul. 2020

4. BRASIL. Ministério da Saúde. Secretaria de Vigilância em Saúde. DOENÇA PELO CORONAVÍRUS 2019. Boletim Epidemiológico 08 - COE Coronavírus. Disponível em: https://www.saude.gov.br/images/pdf/2020/ April/09/be-covid-08-final-2.pdf Acesso em: 17 jul. 2020

5. NOBRE, Akim Felipe Santos et al. Primeira detecção de coronavírus humano associado à infecção respiratória aguda na Região Norte do Brasil. 2014. Disponível em <http://scielo.iec.gov.br/scielo.php?script=sci_arttext\&pid=\$2176-62232014000200005\&lng=pt\&nrm=iso>. Acesso em 14 jul. 2020.

6. NAKAJIMA, Noriko et al. The first autopsy case of pandemic influenza (A) H1N1pdm) virus infection in Japan: detection of a high copy number of the virus in type II alveolar epithelial cells by pathological and virological examination. Jpn J Infect Dis, v. 63, n. 1, p. 67-71, 2010. Disponível em: https:// www.niid.go.jp/niid/JJID/63/67.pdf Acesso em 18 Jul. 2020
7. WERNECK, Guilherme Loureiro; CARVALHO, Marilia Sá. A pandemia de COVID-19 no Brasil: crônica de uma crise sanitária anunciada. 2020. Disponível em: http://cadernos.ensp.fiocruz.br/csp/artigo/1036/a-pandemiade-covid-19-no-brasil-crnica-de-uma-crise-sanitria-anunciada. Acesso em: 18 |ul. 2020

8. APUZZO, M:PRONCZUK, M. Covid-19's Economic Pain is Universal. But Relief? Depends on Where You Live (March 23). New York Times, v. 20, p. 03-23, 2020. Disponível em: https://www.nytimes.com/2020/03/23/world/ europe/coronavirus-economic-relief-wages.html. Acesso em 12 Jul. 2020

9. CAVALIERE, Ivonete Alves de Lima; COSTA, Suely Gomes. Isolamento social, sociabilidades e redes sociais de cuidados. Physis: revista de saude coletiva, v. 21, p. 491-516, 2011. Disponível em: <http://www.scielo.br/scielo.php?script=sci_arttext\&pid=S0103-73312011000200009\&lng=en\&nrm=iso>. Acesso em 14 Jul. 2020.

10. BANDO. Daniel Hideki. Isolamento social, saúde mental e suicídio. 2020. Universidade Federal de Alfenas. Minas Gerais. Disponível em: https:// www.unifal-mg.edu.br/portal/isolamento-social-e-suicidio/ Acesso em:

11. WORLD HEALTH ORGANIZATION et al. Preventing suicide: A global imperative. 2014.Disponível em: http://apps.who.int/iris/bitstr eam/10665/131056/1/9789241564779_eng.pdf?ua=1\&ua=1 Acesso em: 18 Jul. 2020

12. BASSO, Lissia Ana; WAINER, Ricardo. Luto e perdas repentinas: contribuições da Terapia Cognitivo-Comportamental. Revista Brasileira de Terapias Cognitivas, v. 7, n. 1, p. 35-43, 2011. Disponível em <http://pepsic.bvsalud. org/scielo.php?script=sci_arttext\&pid=S1808-56872011000100007\&lng=pt\&nrm=iso>. Acesso em 14 jul. 2020.

13. PARKES, Colin Murray. Luto estudos sobre a perda na vida adulta. Summus editorial, 1998. 